\title{
Effect of phytoplankton bloom deposition on benthic bacterial communities in two contrasting sediments in the southern North Sea
}

\author{
M. A. Franco ${ }^{1,2, *}$, I. De Mesel ${ }^{1}$, M. Demba Diallo ${ }^{3}$, K. Van der Gucht ${ }^{3}$, \\ D. Van Gansbeke ${ }^{1}$, P. van Rijswijk ${ }^{4}$, M. J. Costa ${ }^{2}$, M. Vincx ${ }^{1}$, J. Vanaverbeke ${ }^{1}$ \\ ${ }^{1}$ Marine Biology Section, Biology Department, Ghent University, Krijgslaan 281 (S8), 9000 Ghent, Belgium \\ ${ }^{2}$ Instituto de Oceanografia, Faculty of Sciences, University of Lisbon, Campo Grande, 1749-016 Lisbon, Portugal \\ ${ }^{3}$ Laboratory of Microbiology, Ghent University, KL Ledeganckstraat 35, 9000 Ghent, Belgium \\ ${ }^{4}$ NIOO-KNAW Centre for Estuarine and Marine Ecology, Korringaweg 7, 4401 NT Yerseke, The Netherlands
}

\begin{abstract}
The response of benthic bacterial community composition, diversity, and biomass to phytoplankton deposition was investigated in 2 different sediment horizons at 2 contrasting sites in the southern North Sea. Differences in bacterial community composition between stations were observed. Seasonal differences in bacterial community composition were significant and were stronger in fine sediments, probably related to stronger fluctuations in food availability. Variation in community composition over the vertical sediment profile was different for both stations. In coarser sediment, the difference was mostly due to the absence of certain operational taxonomic units (OTUs) at the surface, while in fine sediment, 2 distinct communities were present. A RELATE test revealed that bacterial community composition was influenced by the amount of labile organic matter (estimated through chl a concentration in the sediment). Diversity in terms of OTU richness and ShannonWeaver diversity index was higher in finer grained sediments. In coarser sediments, diversity at the surface layer was lower, which might be related to stronger hydrodynamic pressure at this station. These differences were not observed at the other station. Seasonal changes in diversity were not detected at either station. Bacterial biomass was slightly higher in finer sediments and was not correlated with either chl a or temperature. Seasonal differences in bacterial biomass followed those observed for community composition, while no vertical differences were detected.
\end{abstract}

KEY WORDS: Benthic bacteria - North Sea - Denaturing gradient gel electrophoresis - DGGE · Community composition $\cdot$ Diversity $\cdot$ Bacterial biomass

\section{INTRODUCTION}

The Belgian Continental Shelf (BCS) is a well mixed, nutrient-rich part of the North Sea (Brussaard et al. 1995), which is characterized by high primary production and algal biomass (Joint \& Pomroy 1993) with a strong seasonality. During spring, Belgian coastal waters are dominated by intense blooms of Phaeocystis colonies co-occurring with diatom blooms (Reid et al. 1990, Joint \& Pomroy 1993, Brussaard et al. 1995). Phaeocystis blooms occur between April and May and last for 20 to $40 \mathrm{~d}$, while diatoms can be present throughout the year with dense blooms occurring as early as February and smaller blooms as late as September (Reid et al. 1990, Rousseau et al. 2002).

The sedimentation of the phytoplankton bloom represents a major source of organic matter for the benthic system (see Billen et al. 1990, Graf 1992). In areas with a strong seasonal cycle of phytoplankton, as in coastal areas, a corresponding seasonality is to be expected in the sedimentation pattern and therefore in the input of organic matter into the benthic system.

It has previously been reported that nematodes responded to a spring bloom deposition by an increase 
in both density and diversity, especially among the selective deposit-feeding nematodes (1A-nematodes; Wieser 1953, Vanaverbeke et al. 2004b) and depositfeeding nematodes (1B-nematodes; Wieser 1953, M. Steyaert et al. unpubl.). This was partially explained by changes in bacterial diversity (Vanaverbeke et al. 2004b), since both 1A and 1B nematodes feed on bacteria (Wieser 1953), and nematodes can selectively feed on particular bacterial strains (Moens et al. 1999, De Mesel et al. 2004).

Bacteria have been reported to react fast on phytoplankton sedimentation in terms of biomass production (larger cells), cell division, and activity, which results in an increase in biomass, density, and productivity (Graf et al. 1982, Meyer-Reil 1983, Goedkoop \& Johnson 1996, Boon et al. 1998). This response of the bacterial community to an input of organic matter seems to be influenced by the covariation of both food supply and temperature (Graf et al. 1982, Boon et al. 1998). Van Duyl \& Kop (1994) indicated temperature and substrate availability for bacteria as the most important factors influencing bacterial production.

However, data concerning possible changes in benthic bacterial community composition and diversity after a mass input of organic matter (OM) are lacking. Applying denaturing gradient gel electrophoresis (DGGE) in microbial ecology allows for simultaneous analyses of multiple samples, which enables monitoring the complex dynamics that microbial communities may undergo by diel and seasonal fluctuations or after environmental perturbations (Muyzer 1999). This technique has been applied successfully to document changes in planktonic bacterial communities during phytoplankton bloom events (e.g. Van Hannen et al. 1999a, Riemann et al. 2000, Fandino et al. 2001, Riemann \& Winding 2001, Van der Gucht et al. 2001, Muylaert et al. 2002, Rooney-Varga et al. 2005).

Here we aimed to examine the bacterial response to a pulsed food supply in terms of community composition, diversity, and biomass at 2 well studied contrasting sites on the BCS. The 2 study sites, Stns $115 \mathrm{bis}$ and 330, are biogeochemically different: 115 bis is a deposition station, characterized by the presence of fine sediments (median grain size: $185 \mu \mathrm{m}$ ), with $4 \%$ of mud (M. Steyaert et al. unpubl.), while Stn 330 has permeable sediment containing medium sand (median grain size: 329 to $361 \mu \mathrm{m}$ ), devoid of mud (Vanaverbeke et al. $2004 a, b)$. This results in strong differences in vertical profiles of chlorophyll (chl) $a$, which is a proxy for the availability of labile OM (Boon \& Duineveld 1996). Especially in depositional stations, the differences in availability of labile OM between sediment depths during and after phytoplankton sedimentation can be striking (Graf 1992), creating very different biogeochemical conditions. After sedimentation of phyto- detritus, the sediment at Stn 115bis can become anoxic and remain so until mid autumn (M. Steyaert et al. unpubl.). As this affects metazoan meiobenthic vertical distribution patterns (Steyaert et al. 1999, M. Steyaert et al. unpubl.), it probably also has important consequences for bacterial life.

In this study, we therefore aimed to test whether there are significant differences in bacterial community composition and biomass (1) between the 2 stations and (2) at the surface and in a deeper sediment layer within a station, and (3) whether there are significant seasonal shifts related to the spring bloom deposition.

\section{MATERIALS AND METHODS}

Study area and sampling. Samples were taken from the BCS Stns 115bis, located close to the coast $\left(51^{\circ} 09.2^{\prime} \mathrm{N}, 02^{\circ} 37.2^{\prime} \mathrm{E} ; 13 \mathrm{~m}\right.$ depth) and 330 , located farther offshore $\left(51^{\circ} 26.0^{\prime} \mathrm{N}, 02^{\circ} 48.5^{\prime} \mathrm{E} ; 20 \mathrm{~m}\right.$ depth; Fig. 1). The sampling sites were never located on slopes or tops of sand banks.

Sampling at both stations was conducted monthly from October 2002 to October 2003 from the RVs 'Zeeleeuw' or 'Belgica.' Sampling took place on the same days at both stations. In December 2002, it was not possible to sample station 330 due to bad weather and sea conditions.

The water column was sampled at $3 \mathrm{~m}$ depth and $1 \mathrm{~m}$ above the sea floor for phytoplankton analysis using 101 Niskin bottles. To obtain pigment samples, $500 \mathrm{ml}$ of water from each depth were filtered onto GF/F glass microfiber filters (i.d. $4.7 \mathrm{~cm}$ ) using a vacuum pump. Three replicated samples were obtained. Water temperature was recorded simultaneously. The samples were kept in the dark and preserved at $-20^{\circ} \mathrm{C}$ on board and stored at $-80^{\circ} \mathrm{C}$ in the laboratory.

Sediment was sampled using a Reineck box corer (surface area $180 \mathrm{~cm}^{2}$ ) or another box corer with a greater surface area (February, April, and October 2003). The box corer was deployed 3 times at each sampling station. In February, only 2 box cores were obtained for station 330.

From each box corer, 2 perspex cores (i.d. $3.6 \mathrm{~cm}$ ) were taken: 1 for pigment analysis and another for bacterial counts and biomass analysis. These cores were sliced in $1 \mathrm{~cm}$ slices down to $10 \mathrm{~cm}$. Pigment samples were preserved at $-20^{\circ} \mathrm{C}$ on board and stored at $-80^{\circ} \mathrm{C}$ in the laboratory. Bacterial counts and biomass samples were preserved in a $4 \%$ formaldehyde-tap water solution, thoroughly shaken, and stored in the fridge until processed further.

During February, April, and October 2003, additional cores for bacterial community composition 


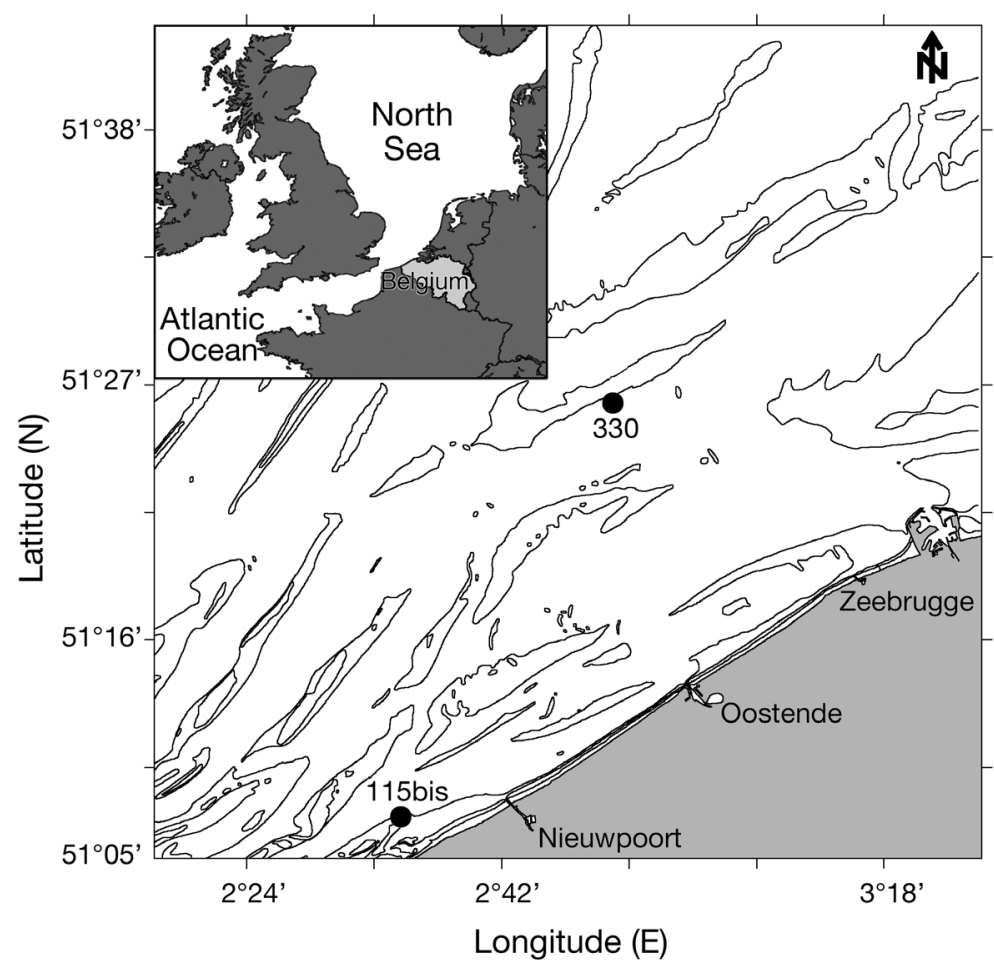

Fig. 1. Sampling stations 115 bis and 330 on the Belgian continental shelf

analysis (i.d. $6 \mathrm{~cm}$ ) were taken. The bacterial cores were carefully closed in order to retain the overlaying water and preserved at $4^{\circ} \mathrm{C}$ until further processing in the laboratory. Additional deployments of the Reineck box corer or other box corer were done to obtain samples for bacterial biomass assessment.

Laboratory treatment of samples. The pigments sediment samples were weighed and pigment contents (chl $a$, phaeophytin, and phaeophorbid) were analyzed by HPLC (Gilson) following Wright \& Jeffrey (1997). The ratio of phaeopigments to the sum of chl a + phaeopigments (PAP ratio) was calculated as an indication of the freshness of the material deposited on the sediment (Boon et al. 1998).

Samples for bacteria counting were prepared following Starink et al. (1994). Milli-Q water was added to the bacterial sample to a volume of $9.5 \mathrm{ml}$, and $0.5 \mathrm{ml}$ $\mathrm{Na}_{2} \mathrm{P}_{2} \mathrm{O}_{7}(0.2 \mathrm{M})$ was added to reach a final concentration of $\mathrm{Na}_{2} \mathrm{P}_{2} \mathrm{O}_{7}$ of $0.01 \mathrm{M}$. This mixture was sonicated 5 times for $30 \mathrm{~s}$ using a Soniprep 150 (10 W). Between sonication pulses, the sample rested on ice for $30 \mathrm{~s}$. Before staining, samples were diluted 10 to $1000 \times$ using Tris. A subsample was filtered onto a $0.2 \mu \mathrm{m}$ polycarbonate filter and stained with Sybrgold (Molecular Probes). Filters were then mounted on a slide. Counting of bacterial cells was performed using a Leica confocal microscope connected to QWIN software. From every image, 16 scans were made $0.2 \mu \mathrm{m}$ vertically apart from each other. In this way, a $3.2 \mu \mathrm{m}$ thick image was analyzed. From each scan, all particles $>0.2 \mu \mathrm{m}$ were counted and allocated to a size class. Per slide, 50 to 100 images were analyzed. The volume of the bacteria was calculated as a sphere volume $(4 \times \pi \times$ $r^{3} / 3 ; r=$ radius), with a radius estimation of half the average of lower (L) and upper (U) diameters, and was converted to carbon content (bacterial biomass) by using a conversion factor of $310 \mathrm{fg}$ of $\mathrm{C}_{\mathrm{m}}^{-3}$ (Fry 1990). Biomass was therefore calculated as: $\left\{4 \times 3.141593 \times[(\mathrm{L}+\mathrm{U}) / 4]^{3} /\right.$ $3\} \times 310$. Data from Stn 115bis were only available from January 2003 onwards.

In a flow bench, 2 subsamples were taken from each of the sediment cores using a sterile syringe from which the tip was removed. From each of the 2 subsamples, the layers between 0 to 1 and 4 to $5 \mathrm{~cm}$ ( $1 \mathrm{ml}$ each) were preserved at $-80^{\circ} \mathrm{C}$ until further processing.

Although in most occasions 3 replicates per station and sediment layers were obtained, methodological problems prevented complete sampling for station 115bis in February (2 replicates from the 0 to $1 \mathrm{~cm}$ layer), in April (1 replicate from the 4 to $5 \mathrm{~cm}$ layer), and in October (2 replicates from the 4 to $5 \mathrm{~cm}$ layer).

DNA extraction. Total DNA was extracted from about $1.5 \mathrm{~g}$ of sediment following the procedure of Demba Diallo (2003). Sediment (1.5 g) was mixed with $1.5 \mathrm{ml} \mathrm{Na} \mathrm{HPO}_{4}(0.1 \mathrm{M})$ and washed by shaking for $30 \mathrm{~min}$ at room temperature. After centrifugation at $7000 \times g\left(10 \mathrm{~min}\right.$ at $\left.4^{\circ} \mathrm{C}\right)$, the supernatant was removed. The pellet was resuspended in $500 \mu$ of lysis buffer ( $2 \%$ cetyltrimethylammonium bromide [CTAB], $0.15 \mathrm{M} \mathrm{NaCl}, 0.1 \mathrm{M} \mathrm{Na}_{2}$ EDTA [pH 8], $1 \%$ polyvinyl polypyrrolidone [PVPP]), and $7.5 \mathrm{mg}$ lysozyme (Sigma) were added. Samples were incubated overnight at $37^{\circ} \mathrm{C}$. We added $25 \mu \mathrm{l}$ of proteinase $\mathrm{K}\left(20 \mathrm{mg} \mathrm{ml}^{-1}\right.$, Boehringer), and the tubes were incubated at $50^{\circ} \mathrm{C}$ for $40 \mathrm{~min}$. The temperature was increased to $65^{\circ} \mathrm{C}$ for $20 \mathrm{~min}$, and $300 \mu \mathrm{l}$ extraction buffer $(0.2 \mathrm{M} \mathrm{NaCl}, 0.1 \mathrm{M}$ Tris- $\mathrm{HCl} \mathrm{pH} 8,2 \% \mathrm{SDS}$ ) were added. The mixture was then incubated at $65^{\circ} \mathrm{C}$ for another $10 \mathrm{~min}$. After addition of $350 \mu$ of $5 \mathrm{M} \mathrm{NaCl}$, the samples were cooled on ice for $15 \mathrm{~min}$. The supernatant was collected after centrifugation $\left(7000 \times g, 10 \mathrm{~min}, 4^{\circ} \mathrm{C}\right)$ and transferred into $2 \mathrm{ml}$ centrifuge tubes. To precipitate the crude DNA, $75 \mu$ of $5 \mathrm{M}$ potassium acetate (Kac) and $250 \mu \mathrm{l}$ $40 \%$ polyethylene glycol 8000 (PEG) were added, and the mixture was incubated at $-80^{\circ} \mathrm{C}$ for $1 \mathrm{~h}$. The pellet, obtained by centrifugation $(13000 \times g$ for $15 \mathrm{~min}$ at $\left.4^{\circ} \mathrm{C}\right)$, was resuspended in $900 \mu \mathrm{l} 2 \times \mathrm{CTAB}(2 \% \mathrm{CTAB}$, 1.4 M NaCl, 0.1 $\mathrm{M} \mathrm{Na}_{2}$ EDTA) and incubated for $15 \mathrm{~min}$ at $68^{\circ} \mathrm{C}$. After addition of $900 \mu \mathrm{l}$ of chloroform, the solu- 
tion was gently mixed and centrifuged at $13000 \times g$ for 10 min at room temperature. The DNA was precipitated by addition of $1 \mathrm{ml}$ of isopropanol and incubated for at least $15 \mathrm{~min}$ at $20^{\circ} \mathrm{C}$. The pellet, obtained by centrifugation $\left(13000 \times g\right.$ for $15 \mathrm{~min}$ at $\left.4^{\circ} \mathrm{C}\right)$, was dissolved in $450 \mu \mathrm{l} 2.5 \mathrm{M}$ ammonium acetate $\left(\mathrm{NH}_{4} \mathrm{OAc}\right)$, and subsequently the DNA was precipitated by the addition of $1000 \mu \mathrm{l} 95 \%$ ethanol and then incubated for at least 15 min at $-20^{\circ} \mathrm{C}$. The pellet of DNA was obtained by centrifugation at $13000 \times g$ for $15 \mathrm{~min}$ at $4^{\circ} \mathrm{C}$ and resuspended in $200 \mu \mathrm{l}$ sterile water (Sigma). For each sediment sample, we performed 2 independent $1.5 \mathrm{~g}$ sediment preparations, of which the purified DNA samples were pooled and stored in a single vial. A $100 \mu \mathrm{l}$ aliquot of the crude extract was further purified using the Wizard ${ }^{\circledR}$ DNA CleanUp kit (Promega).

PCR amplification of 16S rDNA. In total, $6 \mu \mathrm{l}$ (ca. $100 \mathrm{ng}$ ) of the purified DNA were amplified in a Genius temperature cycler. For each sample, 2 PCRs were performed. The PCR mixture contained $6 \mu \mathrm{l}$ of template DNA, $0.5 \mu \mathrm{M}$ of each of the appropriate primers, $200 \mu \mathrm{M}$ of each deoxynucleoside triphosphate, $5 \mu \mathrm{l}$ of $10 \times \mathrm{PCR}$ buffer (100 mM Tris- $\mathrm{HCl} \mathrm{pH}$ 9), $500 \mathrm{mM} \mathrm{KCl}, 15 \mathrm{mM} \mathrm{MgCl} 2,20 \mathrm{ng}$ of bovine serum albumin, and $2.5 \mathrm{U}$ of Taq DNA polymerase (AmpliTaq Perkin Elmer). Each mixture was adjusted to a final volume of $50 \mu \mathrm{l}$ with sterile water (Sigma).

The primers were: F357GC (5'-CGCCCGCCGCGCCCCGCGCCCGGCCCGCCGCCCCCGCCCCCCTA CGGGAGGCAGCAG-3') and R518 (5'-ATTACCGCG GCTGCTGG-3'). Both primers, which were designed by Muyzer et al. (1993), are used to amplify the $16 \mathrm{~S}$ rDNA region corresponding to positions 341 to 534 in Escherichia coli. Primer F357GC, which contains a GCrich clamp, is specific for most bacteria, and R518 is specific for most Bacteria, Archaea, and Eucarya (Van Hannen et al. 1999b). In order to improve the specificity of the amplification and to reduce the formation of spurious by-products, a 'touchdown' PCR (Don et al. 1991, Muyzer et al. 1993) was performed starting with $5 \mathrm{~min}$ at $94^{\circ} \mathrm{C}$, followed by 20 cycles of denaturation at $94^{\circ} \mathrm{C}$ for $1 \mathrm{~min}$, annealing at $65^{\circ} \mathrm{C}$ (the temperature was decreased by $0.5^{\circ} \mathrm{C}$ every cycle until the touchdown temperature of $56^{\circ} \mathrm{C}$ was reached) for $1 \mathrm{~min}$, and primer extension at $72^{\circ} \mathrm{C}$ for $1 \mathrm{~min}$. Ten additional cycles were carried out at an annealing temperature of $55^{\circ} \mathrm{C}$. The tubes were then incubated for $10 \mathrm{~min}$ at $72^{\circ} \mathrm{C}$. The presence of PCR products and their concentration were determined by analyzing $5 \mu \mathrm{l}$ of PCR product on a $2 \%$ agarose gel. A molecular weight marker (SmartladderEurogentec SA) was included.

Denaturing gradient gel electrophoresis (DGGE) analysis. The DGGE technique was carried out using the D-Code System (Bio-Rad Laboratories). The PCR products were loaded onto $8 \%(\mathrm{w} / \mathrm{v})$ polyacrylamide gels of $1 \mathrm{~mm}$ thickness, in $1 \times$ TAE buffer $(20 \mathrm{mM}$ Trisacetate with $\mathrm{pH} 7.4,10 \mathrm{mM}$ acetate, $0.5 \mathrm{mM}$ disodium EDTA). The denaturing gradient contained $35 \%$ to $70 \%$ denaturants $(100 \%$ denaturant corresponded to $7 \mathrm{M}$ urea and $40 \%$ [vol/vol] deionized formamide). The total lane intensity was normalized between the samples at $400 \mathrm{ng}$ of DNA. Electrophoresis was performed at a constant voltage of $75 \mathrm{~V}$ for $16 \mathrm{~h}$ and at a constant temperature of $60^{\circ} \mathrm{C}$. After electrophoresis, the gels were stained for $1 \mathrm{~h}$ in $1 \times$ TAE containing ethidium bromide (0.5 $\mathrm{mg} \mathrm{l}^{-1}$; Muyzer et al. 1993). The bands were visualized on a UV transillumination table equipped with a digital CCD camera.

As standards, we used a mixture of DNA from 9 clones (Van Der Gucht et al. 2001). On each gel, 3 standard lanes were analyzed in parallel to the samples, to facilitate comparison between gels. The banding patterns were then analyzed using Bionumerics 5.1 (Applied Maths BVBA). By measuring an optical density profile through each lane (corresponding to a single sample), this software identifies the band positions and calculates the contribution of the intensity of each band to the total intensity of the lane. This procedure yields a matrix with the relative intensity of each band in all samples.

Bacterial biodiversity. Ecological diversity is considered a function of the number of different classes (richness) and the relative distribution of individuals among these classes (evenness; Washington 1984). By treating each band as an individual 'operational taxonomic unit' (OTU), the richness (number of OTUs present) and the Shannon-Weaver diversity index $\left(H^{\prime}\right.$; Shannon \& Weaver 1963) were calculated using PRIMER 5. As rare populations (less than $1 \%$ of the total community) might not be represented in a DGGE gel (Muyzer et al. 1993), the bacterial community richness (total number of OTUs detected) and diversity (Shannon-Weaver diversity index) calculated here only refer to the dominant bacteria populations and should be interpreted as an indicator of the minimum diversity of the bacterial community.

Statistical analysis. All correlation tests were done using Spearman rank R. STATISTICA 6 software was used, and a confidence level of 0.05 was considered in all test procedures.

The analysis of the banding profiles of the DGGE gels was done by multivariate tests using PRIMER 5 software. All tests were carried out on $\log (x+1)$ transformed data. The Bray-Curtis index was used as a similarity coefficient. A multi-dimensional scaling (MDS) analysis places samples in a multi-dimensional space, based on the similarities between them. In 2D ordination plots, similar samples are therefore placed together (Clarke 1993). The relative intensity of each band was therefore taken into account, which appears 
to be more appropriate than using only presence/ absence of the bands (Muylaert et al. 2002).

One-way analysis of similarity (ANOSIM) was used to test for statistical differences between the community composition of the 2 stations (115bis and 330). For each station, a 2-way crossed ANOSIM was used to test for statistical differences between the community composition at different depths (0 to $1 \mathrm{~cm}$ and 4 to $5 \mathrm{~cm}$ ) and the sampling months February, April, and October 2003 (Clarke 1993). Whenever significant differences were found, pairwise tests were done.

The relationship between chl $a$ and the community structure was assessed by calculating rank correlations between similarity matrices derived from chl a concentration in the sediment and the banding profiles (RELATE procedure) using the software package PRIMER 5. The same RELATE test was used between similarity matrices derived from bacterial counts per size class and bacterial biomass per size class.

One-way and 2-way analyses of variance (ANOVA) were performed to test for statistical differences in the Shannon-Weaver diversity index and OTU richness and in the bacterial counts and biomass for the months of February, April, and October 2003. Homogeneity of variances was tested using Hartley F-max, Cochran $C$, and Bartlett $\chi^{-2}$, and data were transformed whenever necessary. Whenever significant differences were found, a posteriori Tukey HSD tests were performed. One-way ANOVA was used to test for significant differences between the 2 stations. A 2-way ANOVA was used to test for the effect of depth, time, and their interaction for bacterial counts and biomass at both stations and for the Shannon-Weaver diversity index and OTU richness at Stn 330. At Stn 115bis, due to the lack of replication in April in the 4 to $5 \mathrm{~cm}$ layer, a 2-way ANOVA could not be performed on the ShannonWeaver diversity index and OTU richness. One-way ANOVA was then used to test for significant differences between the sampling dates in the 0 to $1 \mathrm{~cm}$ layer; a $t$-test was used to test for significant differences between the sampling dates February and October for the 4 to $5 \mathrm{~cm}$ layer, and a 1-way ANOVA was performed to test for statistical differences between the 2 sampling depths. STATISTICA 6 software was used, and a significance level of 0.05 was considered in all test procedures.

\section{RESULTS}

\section{Environmental variables}

At both stations, the surface and bottom water showed comparable concentrations of chl $a$, indicating a wellmixed water column (Fig. 2). At Stn 115bis, the chl a con- centration in the water was on most occasions higher than at Stn 330. Chl a concentrations in the water at both stations started rising in February, peaked in April (48 $\mathrm{mg} \mathrm{m}^{-3}$ at Stn 115bis and $32 \mathrm{mg} \mathrm{m}^{-3}$ at Stn 330), and decreased afterwards (Fig. 2). Smaller peaks were observed in July for both stations and only at Stn 330 in September, reaching values no higher than $17 \mathrm{mg} \mathrm{m}^{-3}$.

At the sediment surface, chl a concentrations were considerably higher at Stn 115bis than at Stn 330 (Fig. 3) throughout the sampling period and followed the patterns observed in the water column, with a peak in April. At Stn 330, other smaller peaks were observed in August and October 2003, corresponding to the deposition of the late summer and autumn blooms. For both stations, chl $a$ in the bottom water was correlated with the chl $a$ at the sediment surface (115bis: $R=0.73$, $\mathrm{p}<0.05$; 330: $\mathrm{R}=0.62, \mathrm{p}<0.05)$.

At Stn 115bis, the PAP ratio was relatively low in winter, started increasing in April, and remained relatively stable until it reached the highest value in October 2003. At Stn 330, the PAP ratio varied more abruptly, showing a similar value in winter, decreasing abruptly in April, and peaking 2 mo later. From June onwards, the PAP ratio decreased gradually (Fig. 3).

At Stn 115bis, chl a concentration in the sediment was always highest at the surface (Fig. 4). This profile was most evident in April 2003 while deposition was occurring; the PAP ratio showed the opposite trend and increased with depth. At Stn 330, no clear vertical gradient could be found for either chl a concentration or PAP ratio.

Water temperature was lowest in December $\left(4.9^{\circ} \mathrm{C}\right)$, remained low until March, and increased from April onwards. Maximum values were observed in August $\left(22^{\circ} \mathrm{C}\right)$, after which temperature decreased gradually.

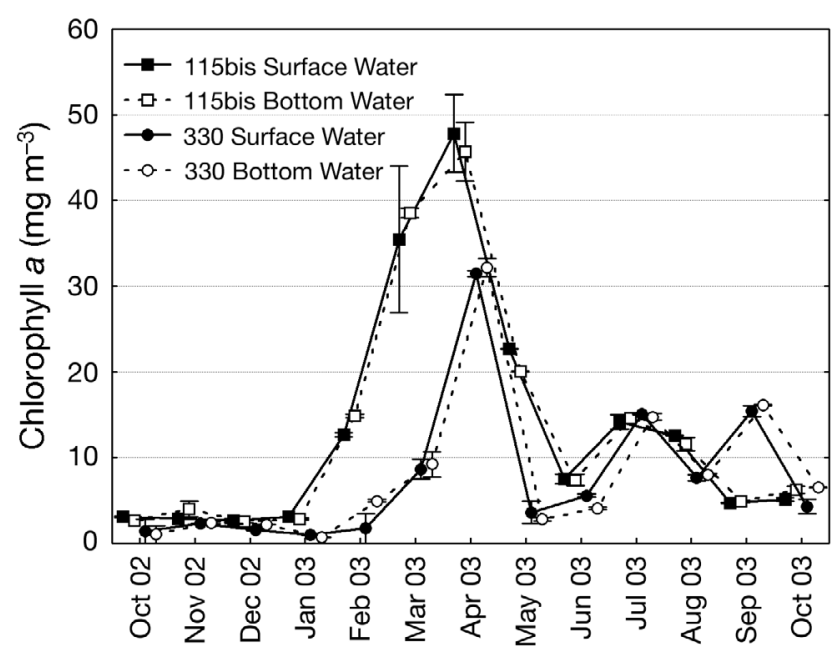

Fig. 2. Chl a concentration in the surface and bottom water $\left(\mathrm{mg} \mathrm{m}^{-3}\right)$ at Stns 115bis and 330 from October 2002 to October 2003. Error bars represent SE 

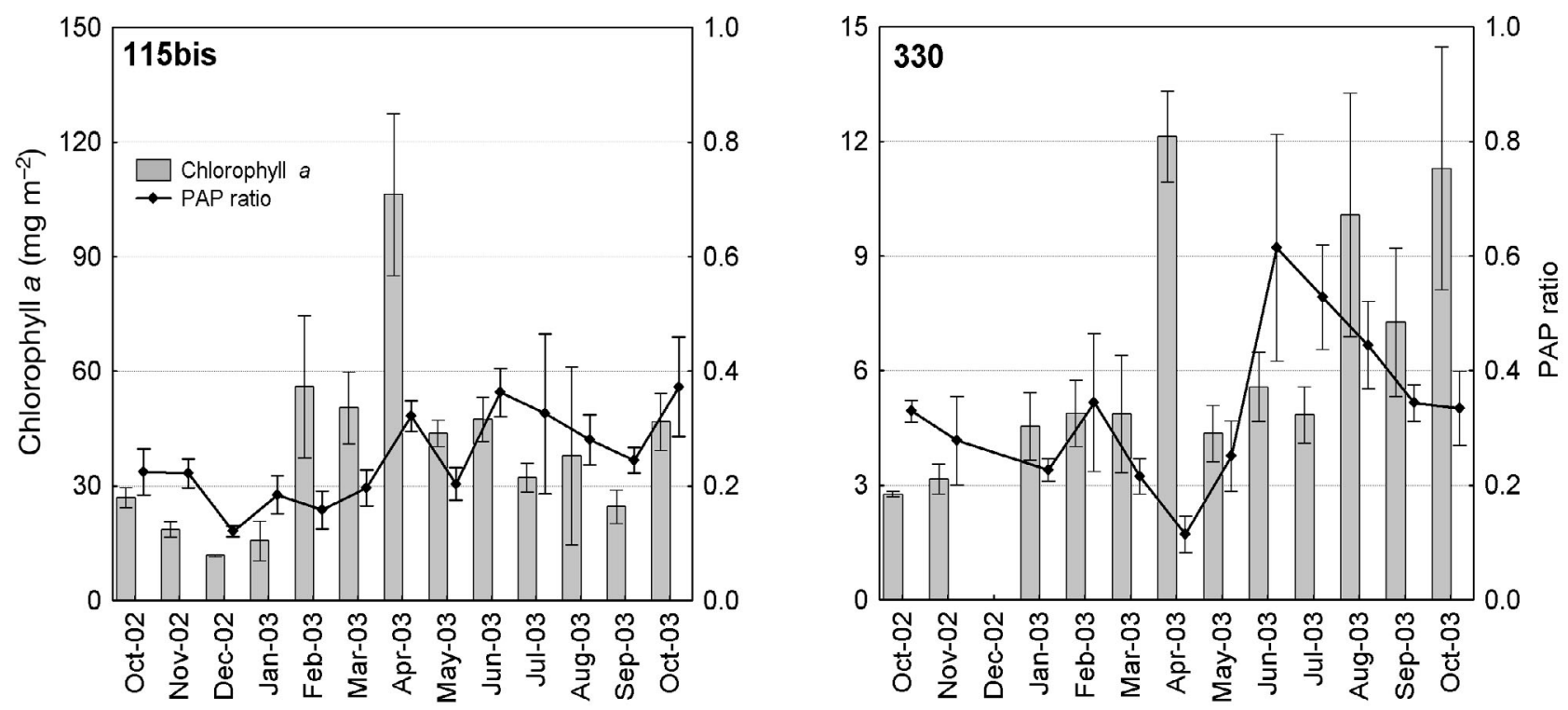

Fig. 3. Chl a concentration in the sediment $\left(\mathrm{mg} \mathrm{m}^{-2}\right)$ and the ratio of phaeopigments to chl $a+$ phaeopigments (PAP ratio) for the 0 to $1 \mathrm{~cm}$ layer at Stns 115bis and 330 from October 2002 to October 2003. Error bars represent SE. Note different scales on left $y$-axes

\section{Bacterial biomass}

Bacterial counts varied between $1.9( \pm 0.3 \mathrm{SE})$ and $14.1( \pm 0.9 \mathrm{SE}) \times 10^{12} \mathrm{~m}^{-2}$ at Stn $115 \mathrm{bis}$ and between 2.0 $( \pm 0.9 \mathrm{SE})$ and $10.6( \pm 4.6 \mathrm{SE}) \times 10^{12} \mathrm{~m}^{-2}$ at Stn 330 (Fig. 5). Bacterial counts were strongly correlated with bacterial biomass $(\mathrm{R}=0.94 ; \mathrm{p}<0.001)$. Moreover, when taking into account the bacterial counts and biomass distributed per size class, a RELATE test revealed a strong relationship between both variables $(\rho=0.90$; $\mathrm{p}<0.01)$. Both tests indicated that bacterial counts and bacterial biomass varied in the same way. Therefore, the results are focused on bacterial biomass, assuming bacterial counts varied in the same way.

The bacterial biomass ranged from $0.2( \pm 0.1 \mathrm{SE})$ to $2.8( \pm 0.8 \mathrm{SE}) \mathrm{gC} \mathrm{m}^{-2}$ at $\mathrm{Stn}$ 115bis and from 0.2 $( \pm 0.1 \mathrm{SE})$ to $1.9( \pm 0.8 \mathrm{SE}) \mathrm{gC} \mathrm{m}^{-2}$ at Stn 330 , showing different seasonal patterns when comparing both stations (Fig. 5). Bacterial biomass at Stn 115bis was much more variable than at Stn 330. Bacterial biomass was low in January and February 2003. Peak values were reached in March 2003, with intermediate values in April and May 2003. A progressive decrease toward initial values was then observed. Bacterial biomass at Stn 330 was lower compared to Stn 115bis, fluctuating around $1 \mathrm{~g} \mathrm{C} \mathrm{m}^{-2}$ from January to July 2003. Prior to and after that period, bacterial biomass values were considerably lower. Biomass at 4 to $5 \mathrm{~cm}$ resembled that in the upper layer in all seasons at both stations (Fig. 5). Biomass showed no correlation with either chl $a$ or temperature $(p>0.05)$ at either station.
Analyzing bacterial biomass for the sampling dates of February, April, and October 2003, no statistical differences were observed between the 2 stations $(F=0.243$, $\mathrm{df}=1, \mathrm{p}>0.05)$. At Stn 115bis, significant differences were found between sampling dates $(F=5.24$, df $=2$, $\mathrm{p}<0.05)$ but not between layers $(F=0.08$, df $=1, \mathrm{p}>$ $0.05)$, nor for the interaction term $(F=0.35$, df $=2, \mathrm{p}>$ 0.05). Post hoc comparisons showed that April significantly differed from February and October. At Stn 330, significant differences were found between sampling dates $(F=5.99, \mathrm{df}=2, \mathrm{p}<0.05)$ but not between layers $(F=0.56, \mathrm{df}=1, \mathrm{p}>0.05)$ nor for the interaction term $(F=0.77$, df $=2, p>0.05)$. Post hoc comparisons showed that April and October were significantly different.

\section{Bacterial community composition}

Each band on the DGGE represents one OTU (Fig. 6). In this study, 52 different OTUs were identified. Only 25 of these were detected at both stations; 21 were found only at Stn 115bis and 6 only at Stn 330 . Twenty-one of the 52 OTUs were detected during the 3 sampling campaigns, while 15 were restricted to 1 sampling period. Sixteen OTUs were detected in only 1 of the 2 layers. Five OTUs were only detected once. A 1-way ANOSIM considering all the samples showed significant differences between the 2 sampling stations (Global R = 0.721; p < 0.05).

MDS carried out for both stations separately revealed seasonal and vertical differences in bacterial 


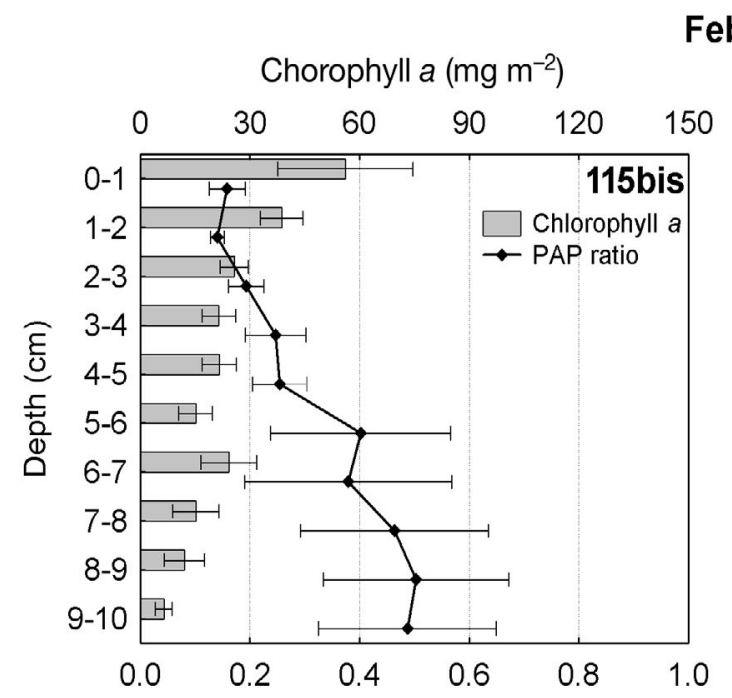

February
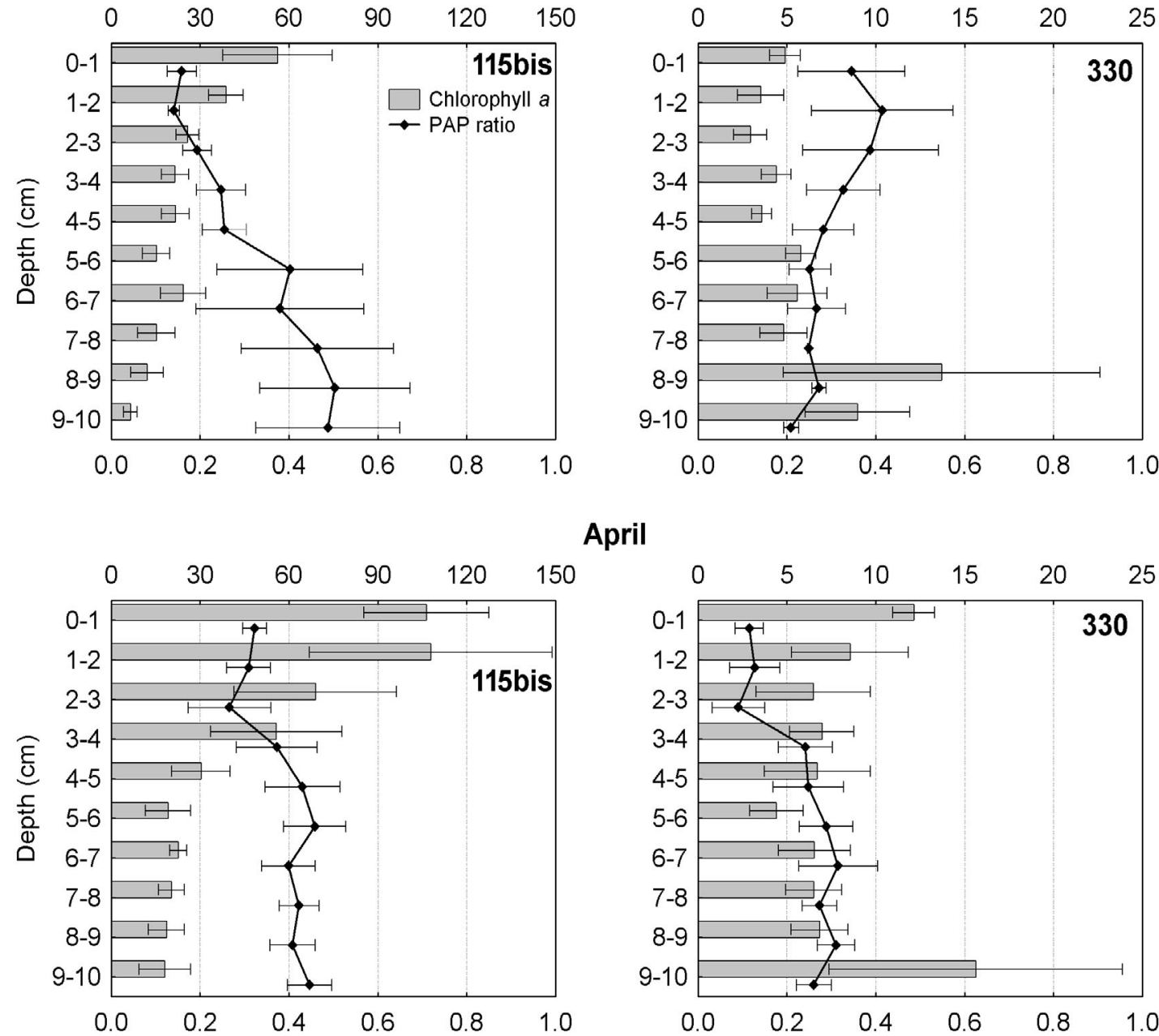

April

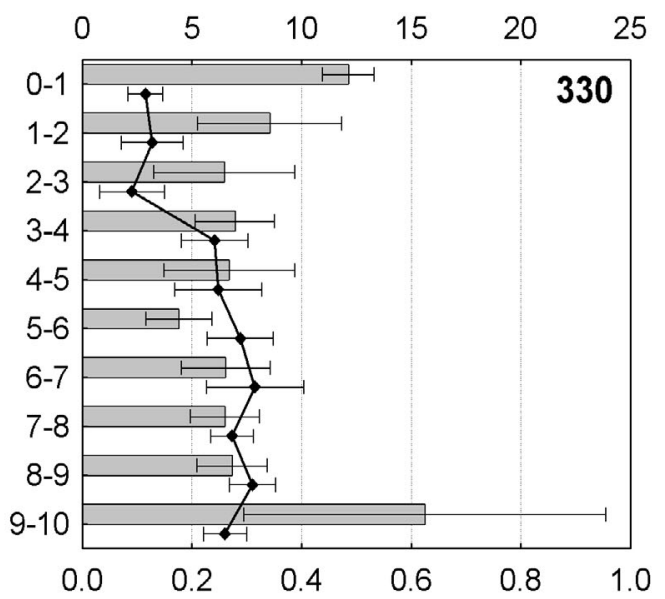

October
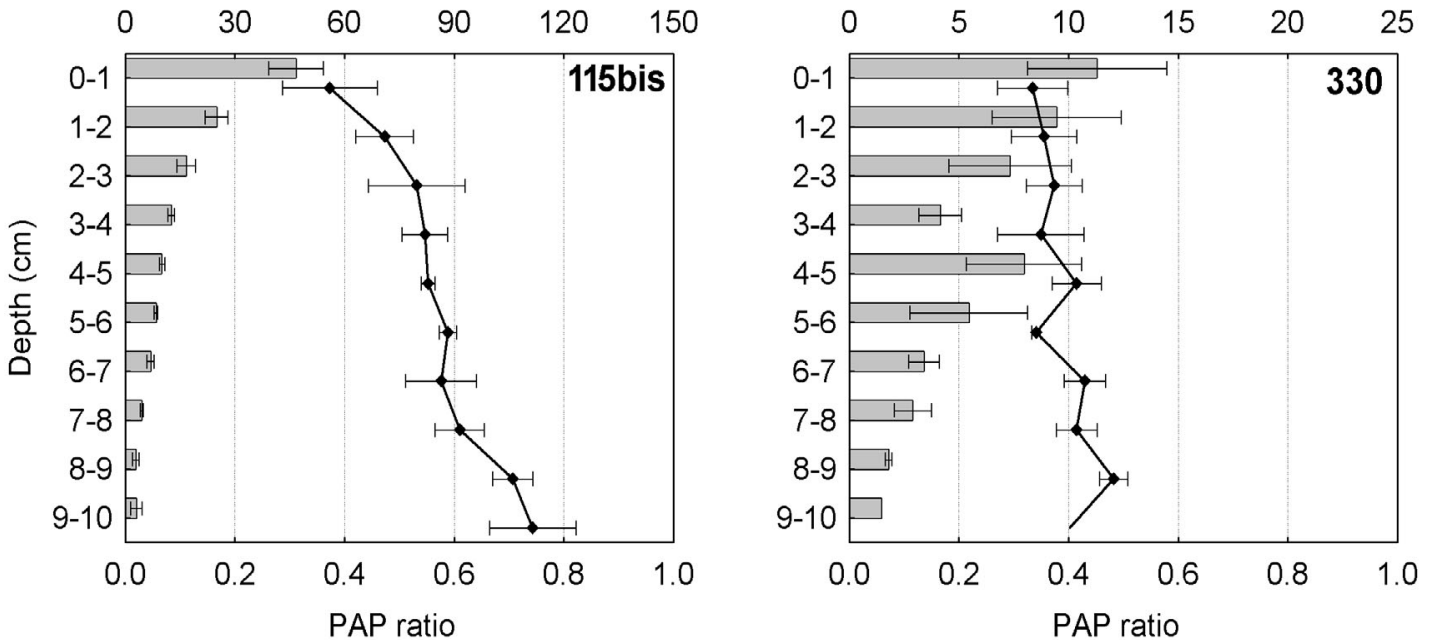

Fig. 4. Vertical profiles of chl a concentration $\left(\mathrm{mg} \mathrm{m}^{-2}\right)$ and ratio of phaeopigments to chl a + phaeopigments (PAP ratio) in the sediment at Stns 115 bis and 330 in February, April, and October 2003. Error bars represent SE. Note different scales on top $X$-axes 

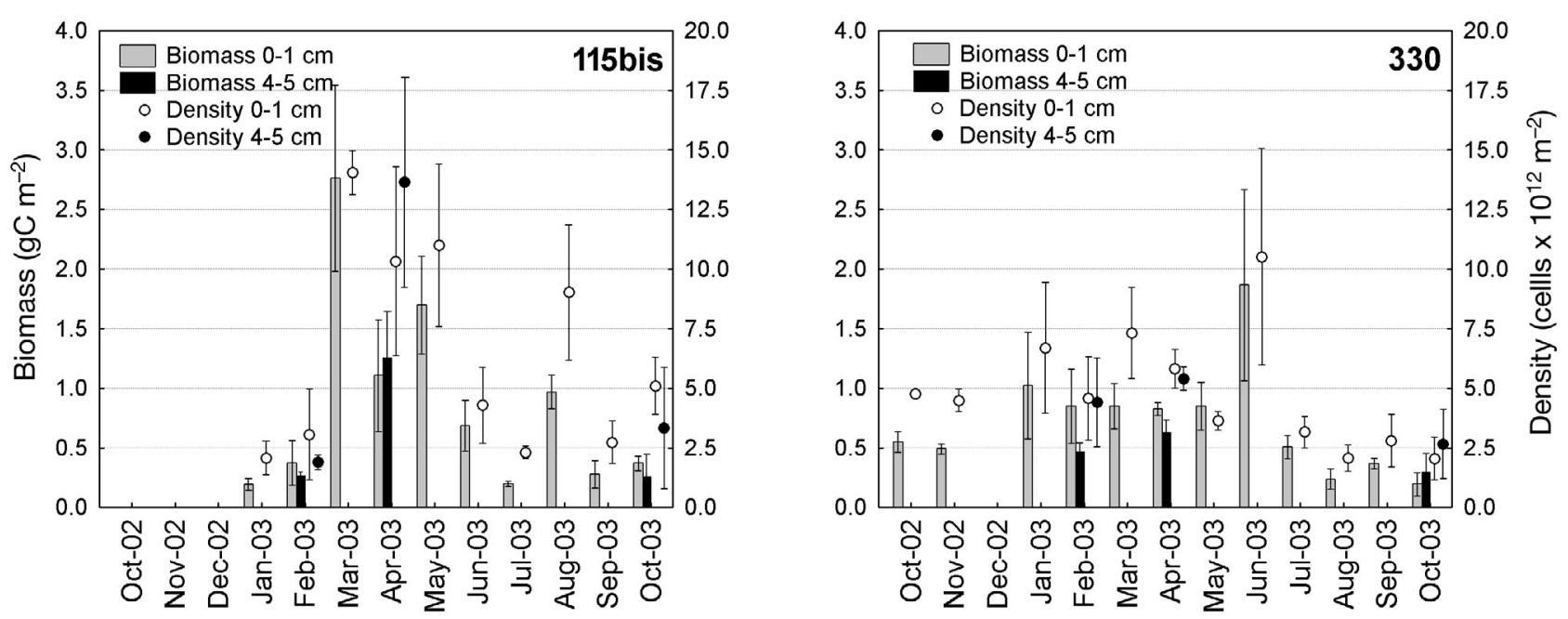

Fig. 5. Bacterial biomass ( $\mathrm{g} \mathrm{C} \mathrm{m}^{-2}$ of sediment) in the 0 to $1 \mathrm{~cm}$ layer from Stns $115 \mathrm{bis}$ and 330 from October 2002 to October 2003. In February 2003, April 2003, and October 2003, the values for the 4 to $5 \mathrm{~cm}$ layer are also indicated. Error bars represent SE

community composition (Fig. 6). When considering Stn 115bis, a 2-way crossed ANOSIM showed significant differences between the sampling months (Global $\mathrm{R}=0.991, \mathrm{p}<0.05$ ) and sediment depths (Global $\mathrm{R}=$ $0.788, \mathrm{p}<0.05)$. When considering pairwise tests (Table 1), all sampling months were significantly different from each other $(\mathrm{p}<0.05)$. At Stn 330, the 2-way crossed ANOSIM again showed significant differences between sampling months (Global $\mathrm{R}=0.884, \mathrm{p}<0.05$ ) and depth layers (Global $\mathrm{R}=0.726, \mathrm{p}<0.05$ ). Pairwise tests (Table 1) revealed that communities in October were significantly different $(p<0.05)$ from those in February and April, while no differences were found between the 2 latter months ( $p>0.05)$.

The bacterial community composition at both stations at all time and depths was significantly influenced by the chl $a$ concentration in the sediment as shown by the significant RELATE test $(\rho=0.26, p<0.05)$.

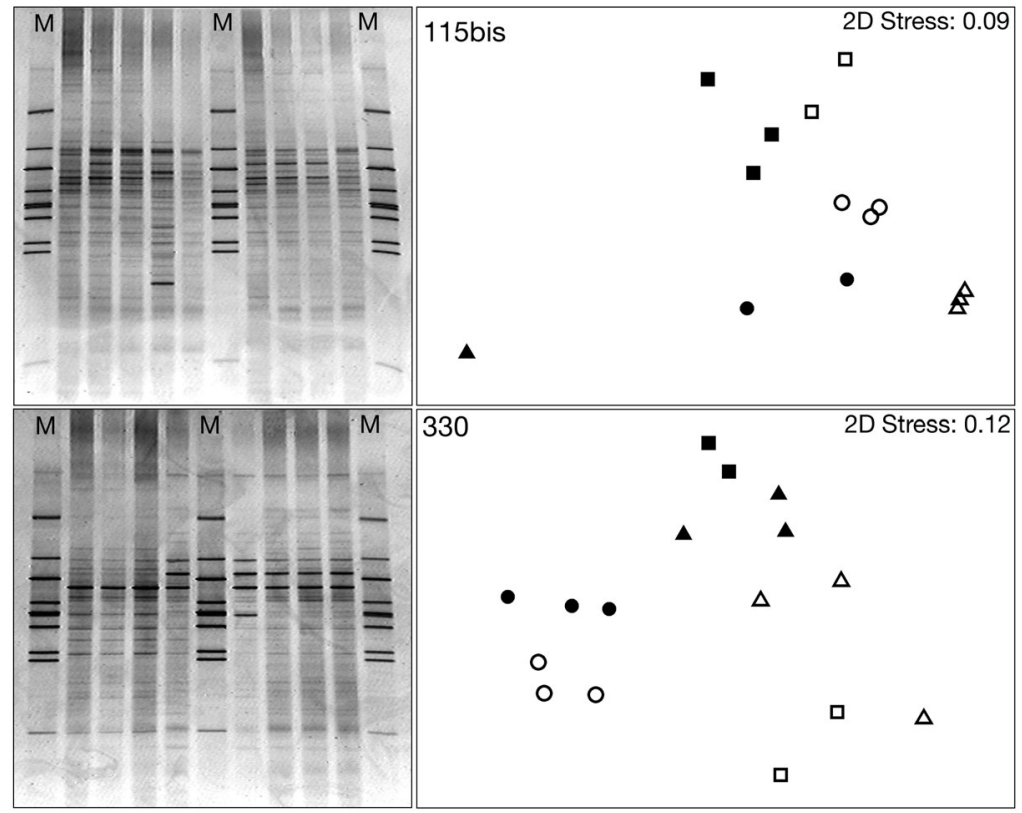

Fig. 6. Example of DGGE gels and MDS analysis of the microbial community from Stns 115bis and 330 of the sampling campaigns in February 2003 (squares), April 2003 (triangles), and October 2003 (circles), in the 0 to $1 \mathrm{~cm}$ (white) and 4 to $5 \mathrm{~cm}$ (black) sediment layers. M: molecular weight marker

\section{Bacterial biodiversity}

Both OTU richness and the ShannonWeaver diversity index were relatively higher at Stn 115bis than at Stn 330 (Fig. 7). At Stn 115bis, OTU richness and Shannon-Weaver diversity index were similar for both sediment layers and for all seasons, with lower values detected only in the 4 to $5 \mathrm{~cm}$ layer in April. The OTU richness and Shannon-Weaver diversity index of the communities at Stn 330 were lower in the surface layer than in the 4 to $5 \mathrm{~cm}$ layer and showed minor changes with time. The sample from 4 to $5 \mathrm{~cm}$ in April at Stn 115bis was removed from the statistical analysis, since it had no replication. A 1-way ANOVA performed on the Shannon-Weaver diversity index showed significant differences between the 2 stations $(F=15.20, \mathrm{df}=1$, $\mathrm{p}<0.001$ ). At Stn 115bis, no significant differences were found between sampling dates for the 0 to $1 \mathrm{~cm}$ layer $(F=$ 
0.035, df $=2, \mathrm{p}>0.05)$; a $t$-test showed no significant differences between February and October for the 4 to $5 \mathrm{~cm}$ layer $(t=0.071, \mathrm{p}>0.05)$, and a 1-way ANOVA showed no significant differences between the 2 depth layers $(F=0.129$, df $=1, \mathrm{p}>0.05)$. At Stn 330, a 2-way ANOVA showed significant differences between the depth layers $(F=14.310, \mathrm{df}=1, \mathrm{p}<0.05)$ but not between sampling months $(F=0.540$, df $=2, \mathrm{p}>0.05)$, nor when combining both effects $(F=1.312$, df $=2, \mathrm{p}>$ 0.05). The same analyses performed on the OTU richness showed the same significant differences as shown by the bacterial Shannon-Weaver diversity index.

\section{DISCUSSION}

\section{Environmental variables}

As described previously (Vanaverbeke et al. 2004a,b, M. Steyaert et al. unpubl.) a strong phytoplankton bloom occurred in spring as indicated by the seasonal pattern of the concentration of chl $a$ in the water column. The higher chl a concentration in the water column at Stn 115bis during the spring phyto-

Table 1. Pairwise test for bacterial community composition in the different sampling months for both stations. ${ }^{*} \mathrm{p}<0.05$

\begin{tabular}{|c|c|c|c|c|}
\hline & \multicolumn{2}{|c|}{$\ldots$ Stn 115bis } & \multicolumn{2}{|c|}{$-\operatorname{Stn} 330-$} \\
\hline & R statistic & $\begin{array}{c}\text { Signif. } \\
\text { level }\end{array}$ & R statistic & $\begin{array}{c}\text { Signif. } \\
\text { level }\end{array}$ \\
\hline Feb vs. Apr & 0.958 & $0.010^{*}$ & 0.500 & 0.080 \\
\hline Feb vs. Oct & 1.000 & $0.025^{*}$ & 1.000 & $0.010^{*}$ \\
\hline Apr vs. Oct & 1.000 & $0.033^{*}$ & 0.944 & $0.010^{*}$ \\
\hline
\end{tabular}

plankton bloom was to be expected, since primary production is higher closer to the coast (Joint \& Pomroy 1993).

Patterns of chl a concentrations in the sediment also showed a strong seasonal signal as already described (Vanaverbeke et al. 2004a,b, M. Steyaert et al. unpubl.), but in contrast to the water column values, differed considerably between the stations. Chl a concentration at the sediment surface at Stn 115bis was about $10 \times$ higher than at Stn 330 . This, together with the absence of clear vertical profiles in the sediment, corroborated the idea that Stn 330 has more permeable sediment, where stronger bottom water currents prevent the deposition of sedimenting phytodetritus (Precht \& Huettel 2004) and induce subsurface chl a peaks (Ehrenhauss \& Huettel 2004, Ehrenhauss et al. 2004a). At Stn 115bis, vertical gradients were very obvious, especially during the deposition of the phytoplankton bloom, corroborating that 115 bis is a deposition station.

The pattern of the PAP ratios showed little seasonal variation at Stn 115bis compared to Stn 330 (Fig. 3). The comparatively higher PAP ratio at Stn 330 following bloom senescence indicate a rapid degradation of organic matter, which is typical of permeable coastal sands (Ehrenhauss et al. 2004b). Advective transport allows fast removal of decomposition products (Huettel et al. 1998) resulting in an up and down fluctuation of the PAP ratio at Stn 330. At Stn 115bis, there was a carbon build-up (phytodetritus derived) in the sediment during spring and subsequent degradation and mineralization in late summer as previously reported in the North Sea for this type of sediment (Boon \& Duineveld 1998, P. Provoost et al. unpubl.). Therefore, the PAP ratio did not show major fluctuations but slowly increased toward late summer and autumn.
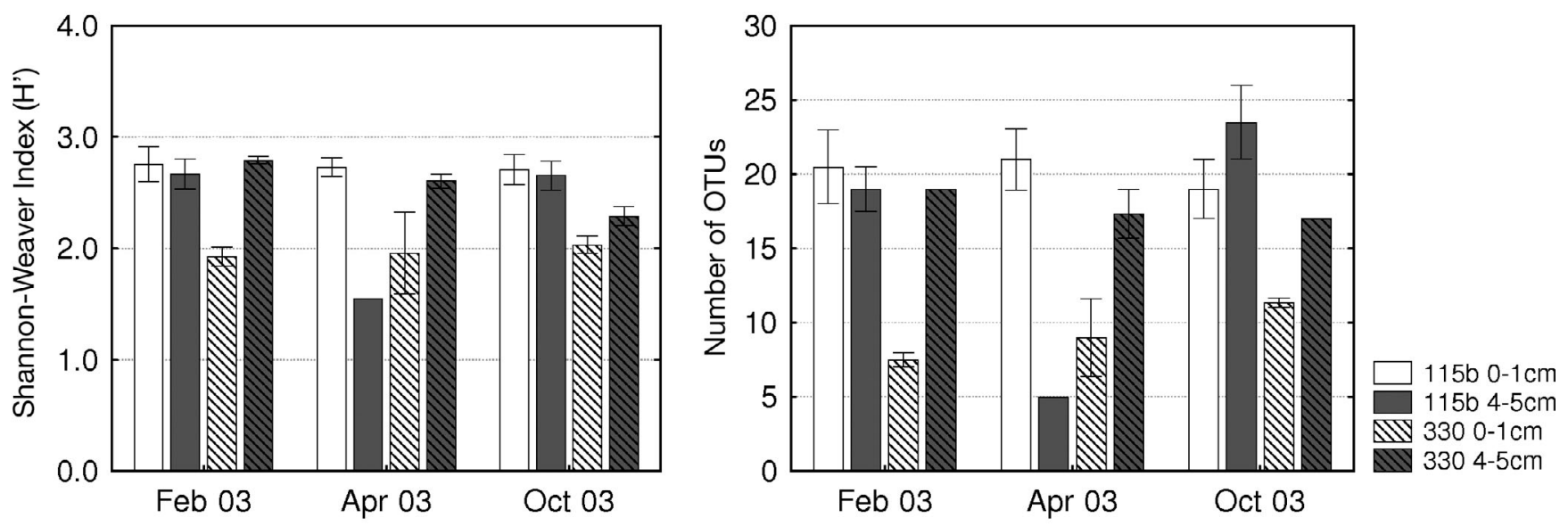

Fig. 7. Shannon-Weaver index $\left(H^{\prime}\right)$ and number of OTUs identified in the bacterial community from Stns $115 \mathrm{bis}$ and 330 in the sampling campaigns in February 2003, April 2003, and October 2003, in the 0 to $1 \mathrm{~cm}$ and 4 to $5 \mathrm{~cm}$ sediment layers. Error bars represent $\mathrm{SE}$ 


\section{Bacterial biomass}

Bacterial counts make no distinction between dead, active, or inactive bacteria. Coastal marine sediments contain a large fraction of dead or inactive bacteria (Luna et al. 2002), and the percentage of active bacteria may change rapidly (Créach et al. 2003). In deep Mediterranean sediments, the number of active bacteria depends on the organic substrate in the sediment derived from the photic layer (Luna et al. 2004). However, according to the same study, no relationship was observed between total bacterial counts and the content of organic substrates in the sediment. In our study, bacterial biomass, calculated from bacterial counts, also had no correlation with either temperature or chl a (as an indicator of the amount of labile OM) at either station. Both temperature and food availability seem to be key factors influencing the response of benthic bacterial communities to an input of organic matter (Graf et al. 1982, Boon et al. 1998), and a relationship between bacterial community composition and chl a concentration in the sediment was detected. Bacterial biomass and/or counts alone might not be a reliable indicator of changes in bacterial activity, although coupled with other data, like DGGE banding profiles, they can help achieve a better understanding of changes in the bacterial community. A significantly higher biomass was detected in April at Stn 115bis (compared to February and October), which can be coupled with the seasonal shifts in bacterial community composition observed at this station (discussed below, in 'Bacterial community composition and diversity'). Also, a significantly lower biomass detected in October at Stn 330 might be the cause of this community composition being significantly different from that in February and April (discussed below, in 'Bacterial community composition and diversity').

\section{Methodological considerations}

As with any PCR and DNA based techniques, DGGE of PCR-amplified 16S rDNA (Muyzer et al. 1993) has its own methodological limitations, including the inhibition of PCR amplification by co-extracted contaminants, deferential amplification, or formation of artefactual PCR products or contaminating DNA, and 16S rRNA sequence variations. Co-migration of DNA, single bands representing more then 1 bacterial strain or slightly different rRNA gene sequences resulting in multiple bands are problems that can occur in DGGE gels (Nübel et al. 1996, Palys et al. 1997, Vallaeys et al. 1997). Nevertheless, PCR-mediated analysis of 16S rRNA is a powerful tool for the determination of microbial diversity of environmental ecosystems (von
Wintzingerode et al. 1997), and DGGE techniques are quite effective when characterizing bacterial community structure, particularly for monitoring changes in occurrence and/or relative frequency of the different bacterial populations (Fromin et al. 2002). Since samples were treated in the same way during the whole study, the method allows for a proper comparison of the results beyond a mere qualitative approach (Fromin et al. 2002). The Shannon-Weaver index is the most common diversity index generally used by ecologists (Washington 1984) and has also been applied to DGGE fingerprints to estimate bacterial diversity (e.g. Nübel et al. 1999, Boon et al. 2002, Dilly et al. 2004, Haack et al. 2004, Gafan et al. 2005, Xia et al. 2005, Lagacé et al. 2006), even though in a DGGE gel, populations representing less than $1 \%$ of the total community might not be represented (Muyzer et al. 1993).

\section{Bacterial community composition and diversity}

Our results showed that bacterial community composition was significantly different at both stations. Only 6 of the 52 OTUs were exclusively detected at Stn 330, while 21 OTUs were found exclusively at Stn 115bis (data not shown). OTU richness and Shannon-Weaver diversity index were mostly higher at Stn 115bis than at Stn 330, especially at the sediment surface. This may be a reflection of higher food availability at Stn 115bis, since substrate availability affects the bacterial community composition (Van Hannen et al. 1999a, Muylaert et al. 2002) and a high concentration of potentially available substrate can sustain a higher bacterial diversity (Luna et al. 2004). Even though we did not detect the whole community by means of DGGE, the results on the dominant OTU (relative density higher than $1 \%$ ) seem to indicate a relatively more diverse community at Stn 115bis.

In bacterioplankton, both free-living bacteria and particle-associated bacteria can occur as 2 distinct communities (Fandino et al. 2001, Riemann \& Winding 2001, Rooney-Varga et al. 2005), although this should not be generalized (Sapp et al. 2007). If this were true for the sediment as well, we would expect that the establishment of free-living bacteria populations would become more difficult at Stn 330 due to the high bottom water currents and the permeability of the sediment. This would be more evident at the surface of the sediment, where our results indicate the lowest bacterial diversity for Stn 330. At Stn 115bis with no such currents, both free-living and attached bacteria could coexist as they can in the plankton.

Another factor that could be responsible for different community composition at both stations is the possible coexistence of aerobic and anaerobic bacteria at Stn 115bis. At this station, the sediment becomes reduced 
after a spring bloom (M. Steyaert et al. unpubl.), while at Stn 330, sediments at the depths studied are well aerated (Vanaverbeke et al. 2004a,b).

Significant vertical differences in bacterial community composition were observed at both stations, which might have different causes at each station. Only 1 OTU was found exclusively at the surface layer at Stn 330. This OTU was also found exclusively at the surface layer at Stn 115bis. All other OTU encountered at the surface were also found in the 4 to $5 \mathrm{~cm}$ layer, generally with relatively higher densities. Twelve OTUs were found exclusively in the 4 to $5 \mathrm{~cm}$ layer at Stn 330, half of which were also observed at the sediment surface at Stn 115bis (data not shown). The differences in the community composition between the 2 layers at Stn 330 were a consequence of the nondetection of certain bacterial populations at the surface of the sediment. Bacterial populations in the upper layers of Stn 330 might not be able to cope with the high hydrodynamic stress (advective currents through the sediment) prevailing there (Precht \& Huettel 2004), which results in both lower Shannon-Weaver diversity index and number of OTUs, and different bacterial community composition compared to deeper layers.

At Stn 115bis, 10 OTUs were found exclusively at the surface and 8 OTUs only in the 4 to $5 \mathrm{~cm}$ layer (data not shown), indicating that at this station different communities might have developed at each layer. If the sample from the 4 to $5 \mathrm{~cm}$ layer in April at Stn 115bis was omitted, no significant differences were observed in the Shannon-Weaver diversity index and OTU richness between layers, even though community composition was different. At this sampling occasion, it was only possible to obtain 1 replicate for the 4 to $5 \mathrm{~cm}$ layer. The DNA extraction and consequent PCR was not as successful as for other samples. Since bacterial biomass was not lower, this might be related to chemical inhibition. Because there was no replication, results referring to the 4 to $5 \mathrm{~cm}$ layer layer at Stn 115bis in April should be interpreted with care.

Steep vertical gradients in chl a concentration and PAP ratio were registered at station 115bis. Moreover, deep sediment layers at this station showed strong negative redox potential values and a build-up of $\mathrm{NH}_{4}^{+}$ (M. Steyaert et al. unpubl.). Vertical differences in the benthic bacterial community have previously been reported (Luna et al. 2004) in Mediterranean sediments with oxygen depletion problems in which the vertical differences in the bacterial community were closely related to redox potential changes (Urakawa et al. 2000).

The statistical analysis of the DGGE fingerprints also showed that bacterial community composition at both stations changed with time. In the planktonic system, shifts in plankton species composition are responsible for changes in the attached bacterial community composi- tion (Rooney-Varga et al. 2005). Carbon-rich mucilage sedimentation, as secreted by Phaeocystis, can be a postbloom food source (Riebesell et al. 1995). Experimental degradation of such compounds in agar from different sources and under different oxygen conditions presented very different microbial communities with only a few overlapping species (Janse et al. 2000). Changes in organic matter quality and quantity can induce shifts in bacterial community structure (Luna et al. 2004). Therefore, seasonal changes in food availability and oxygenation are likely to produce distinct bacterial communities. This was supported by the significant RELATE test observed between the bacterial community composition and the concentration of chl $a$ in the sediment.

Temporal differences in bacterial composition were stronger at Stn 115bis, where all sampling months were significantly different from each other. Also, the percentage of OTUs that were present in the 3 sampling campaigns was lower at Stn 115bis than at Stn 330 (data not shown), indicating higher shifting of the bacterial populations at this station. Moreover, bacterial biomass was higher in April, implying shifts in bacterial biomass from February to April and again from April to October. Stronger variations in chl a concentration in the sediment at Stn 115bis, probably also related to shifts in bacterial biomass, would imply higher temporal differences in the bacterial community composition at Stn 115bis.

Besides food availability, the oxygenation of the sediment can also change more drastically at Stn 115bis (M. Steyaert et al. unpubl.), which is not the case for Stn 330 where the redox potential remains positive throughout the studied sediment depths (Vanaverbeke et al. 2004a,b).

At Stn 330, the bacterial community composition in October differed from the other 2 sampling campaigns, which was also the case for bacterial biomass. Temporal variability was also present at this station, albeit not strongly.

Even though the bacterial community composition changed with time, such differences were not detected in the Shannon-Weaver diversity index and OTU richness at Stn 330, nor at Stn 115bis when the sample from the 4 to $5 \mathrm{~cm}$ layer in April was omitted. At each station, we observed that with time OTUs were disappearing, new ones were emerging, and others were always present but their density changed. The regular seasonal environmental changes might be responsible for maintenance of diversity, since environmental fluctuations can provide temporal niche opportunities, allowing species to coexist (Chesson \& Huntly 1997). This does not mean that the same bacteria were not always present, but changes in dominance might push certain bacteria above the detection limit (Hedrick et al. 2000). 


\section{CONCLUSIONS}

We have shown that bacterial community composition differed when comparing fine and coarser marine sediments, and our results indicated that diversity in general tends to be higher in finer sediments. Bacterial community composition also differed vertically within the sediment, but not in the same way for both sediment types. In the fine sediment, 2 relatively distinct communities developed at the surface and deeper in the sediment. In coarser sediments, vertical differences were related mostly to the non-detection of certain bacteria populations at the surface of the sediment where hydrodynamic stress is stronger. Seasonal patterns in food availability played a key role in the bacterial community composition, which changed more drastically within fine sediment, where the input of organic matter was stronger.

These changes in bacterial community may also be of importance when considering higher trophic levels. Changes in nematode community composition after bloom sedimentation toward feeding types that feed on bacteria has been observed at these 2 stations (Vanaverbeke et al. 2004b, M. Steyaert et al. unpubl.). Vanaverbeke et al. (2004b) hypothesized that an increase in nematode species richness could have been caused by an increase in bacterial diversity. Indeed, a shift in bacterial community composition was observed.

Acknowledgements. We thank the master and crew of the RVs 'Belgica' and 'Zeeleeuw' for their skillful help during sampling. L. Moodley and L. van Ijzerloo are acknowledged for their contribution to the sampling and handling of bacterial biomass samples. Prof. Dr. Jean Swings is acknowledged for allowing us to use his laboratory facilities. This research was funded by the Belgian Science Policy (TROPHOS - Contract no. EV/02/25A), UGENT-BOF project 01GZ0705 Biodiversity and Biogeography of the Sea (BBSea) (2005-2010). M.A.F. was financially supported by a PhD grant from the Foundation for Science and Technology (FCT - SFRH/BD/10386/2002). We acknowledge the support from the MarBEF Network of Excellence 'Marine Biodiversity and Ecosystem Functioning,' which is funded by the Sustainable Development, Global Change and Ecosystems Programme of the European Community's Sixth Framework Programme (contract no. GOCE-CT-2003505446). This publication is contribution number MPS-07032 of MarBEF and publication no. 4074 from NIOO-CEME.

\section{LITERATURE CITED}

Billen G, Joiris C, Meyerreil L, Lindeboom H (1990) Role of bacteria in the North-Sea Ecosystem. Neth J Sea Res 26: 265-293

Boon AR, Duineveld GCA (1996) Phytopigments and fatty acids as molecular markers for the quality of near-bottom particulate organic matter in the North Sea. J Sea Res 35: 279-291
Boon AR, Duineveld GCA (1998) Chlorophyll $a$ as a marker for bioturbation and carbon flux in southern and central North Sea sediments. Mar Ecol Prog Ser 162:33-43

Boon AR, Duineveld GCA, Berghuis EM, van der Weele JA (1998) Relationships between benthic activity and the annual phytopigment cycle in near-bottom water and sediments in the southern North Sea. Estuar Coast Shelf Sci 46:1-13

Boon N, De Windt W, Verstraete W, Top EM (2002) Evaluation of nested PCR-DGGE (denaturing gradient gel electrophoresis) with group-specific 16S rRNA primers for the analysis of bacterial communities from different wastewater treatment plants. FEMS Microbiol Ecol 39:101-112

Brussaard CPD, Riegman R, Noordeloos AAM, Cadee GC and 5 others (1995) Effects of grazing, sedimentation and phytoplankton cell-lysis on the structure of a coastal pelagic food web. Mar Ecol Prog Ser 123:259-271

Chesson P, Huntly N (1997) The roles of harsh and fluctuating conditions in the dynamics of ecological communities. Am Nat 150:519-553

Clarke KR (1993) Non-parametric multivariate analyses of change in community structure. Aust J Ecol 18:117-143

Créach V, Baudoux AC, Bertru G, Le Rouzic B (2003) Direct estimate of active bacteria: CTC use and limitations. J Microbiol Methods 52:19-28

Demba Diallo M (2003) Molecular study of the microbial community in pasture soil under Acacia tortilis subsp. raddiana and Balanites aegyptiaca in North Senegal. PhD thesis, Ghent University

De Mesel I, Derycke S, Moens T, Van der Gucht K, Vincx M, Swings J (2004) Top-down impact of bacterivorous nematodes on the bacterial community structure: a microcosm study. Environ Microbiol 6:733-744

Dilly O, Bloem J, Vos A, Munch JC (2004) Bacterial diversity in agricultural soils during litter decomposition. Appl Environ Microbiol 70:468-474

Don RH, Cox PT, Wainwright BJ, Baker K, Mattick JS (1991) Touch down PCR to circumvent spurious priming during gene amplification. Nucleic Acids Res 19:503-514

Ehrenhauss S, Huettel M (2004) Advective transport and decomposition of chain-forming planktonic diatoms in permeable sediments. J Sea Res 52:179-197

Ehrenhauss S, Witte U, Bühring SL, Huettel M (2004a) Effect of advective pore water transport on distribution and degradation of diatoms in permeable North Sea sediments. Mar Ecol Prog Ser 271:99-111

Ehrenhauss S, Witte U, Janssen F, Huettel M (2004b) Decomposition of diatoms and nutrient dynamics in permeable North Sea sediments. Cont Shelf Res 24:721-737

Fandino LB, Riemann L, Steward GF, Long RA, Azam F (2001) Variations in bacterial community structure during a dinoflagellate bloom analyzed by DGGE and 16S rDNA sequencing. Aquat Microb Ecol 23:119-130

Fromin N, Hamelin J, Tarnawski S, Roesti D and 6 others (2002) Statistical analysis of denaturing gel electrophoresis (DGE) fingerprinting patterns. Environ Microbiol 4: $634-643$

Fry JC (1990) Direct methods and biomass estimation. Methods Microbiol 22:41-85

Gafan GP, Lucas VS, Roberts GJ, Petrie A, Wilson M, Spratt DA (2005) Statistical analyses of complex denaturing gradient gel electrophoresis profiles. J Clin Microbiol 43: 3971-3978

Goedkoop W, Johnson, RK (1996) Pelagic-benthic coupling: profundal benthic community response to spring diatom deposition in mesotrophic Lake Erken. Limnol Oceanogr 41:636-647 
Graf G (1992) Benthic-pelagic coupling - a benthic view. Oceanogr Mar Biol 30:149-190

Graf G, Bengtsson W, Diesner U, Schulz R, Theede H (1982) Benthic response to sedimentation of a spring phytoplankton bloom - process and budget. Mar Biol 67:201-208

Haack SK, Fogarty LR, West TG, Alm EW, McGuire JT, Long DT, Hyndman DW, Forney LJ (2004) Spatial and temporal changes in microbial community structure associated with recharge-influenced chemical gradients in a contaminated aquifer. Environ Microbiol 6:438-448

Hedrick DB, Peacock A, Stephen JR, Macnaughton SJ, Bruggemann J, White DC (2000) Measuring soil microbial community diversity using polar lipid fatty acid and denaturing gradient gel electrophoresis data. J Microbiol Methods 41:235-248

Huetttel M, Ziebis W, Forster S, Luther GW (1998) Advective transport affecting metal and nutrient distributions and interfacial fluxes in permeable sediments. Geochim Cosmochim Acta 62:613-631

Janse I, Zwart G, van der Maarel MJEC, Gottschal JC (2000) Composition of the bacterial community degrading Phaeocystis mucopolysaccharides in enrichment cultures. Aquat Microb Ecol 22:119-133

Joint I, Pomroy A (1993) Phytoplankton biomass and production in the southern North Sea. Mar Ecol Prog Ser 99: 169-182

Lagacé L, Jacques M, Mafu AA, Roy D (2006) Compositions of maple sap microflora and collection system biofilms evaluated by scanning electron microscopy and denaturing gradient gel electrophoresis. Int J Food Microbiol 109: 9-18

Luna GM, Manini E, Danovaro R (2002) Large fraction of dead and inactive bacteria in coastal marine sediments: comparison of protocols for determination and ecological significance. Appl Environ Microbiol 68:3509-3513

Luna GM, Dell'Anno A, Giuliano L, Danovaro R (2004) Bacterial diversity in deep Mediterranean sediments: relationship with the active bacterial fraction and substrate availability. Environ Microbiol 6:745-753

Meyer-Reil LA (1983) Benthic response to sedimentation events during autumn to spring at a shallow-water station in the western Kiel Bight 2. Analysis of benthic bacterialpopulations. Mar Biol 77:247-256

Moens T, Verbeeck L, de Maeyer A, Swings J, Vincx M (1999) Selective attraction of marine bacterivorous nematodes to their bacterial food. Mar Ecol Prog Ser 176:165-178

Muylaert K, Van der Gucht K, Vloemans N, De Meester L, Gillis M, Vyverman W (2002) Relationship between bacterial community composition and bottom-up versus topdown variables in four eutrophic shallow lakes. Appl Environ Microbiol 68:4740-4750

Muyzer G (1999) DGGE/TGGE: a method for identifying genes from natural ecosystems. Curr Opin Microbiol 2: 317-322

Muyzer G, Dewaal EC, Uitterlinden AG (1993) Profiling of complex microbial populations by denaturing gradient gel electrophoresis analysis of polymerase chain reactionamplified genes coding for $16 \mathrm{~s}$ ribosomal RNA. Appl Environ Microbiol 59:695-700

Nübel U, Engelen B, Felske A, Snaidr J, Wieshuber A, Amann RI, Ludwig W, Backhaus H (1996) Sequence heterogeneities of genes encoding 16S rRNAs in Paenibacillus polymyxa detected by temperature gradient gel electrophoresis. J Bacteriol 178:5636-5643

Nübel U, Garcia-Pichel F, Kuhl M, Muyzer G (1999) Quantifying microbial diversity: morphotypes, 16S rRNA genes, and carotenoids of oxygenic phototrophs in microbial mats. Appl Environ Microbiol 65:422-430

Palys T, Nakamura LK, Cohan FM (1997) Discovery and classification of ecological diversity in the bacterial world: the role of DNA sequence data. Int J Syst Bacteriol 47: 1145-1156

Precht E, Huettel M (2004) Rapid wave-driven advective pore water exchange in a permeable coastal sediment. J Sea Res 51:93-107

Reid PC, Lancelot C, Gieskes WWC, Hagmeier E, Weichart G (1990) Phytoplankton of the North Sea and its dynamics a review. Neth J Sea Res 26:295-331

Riebesell U, Reigstad M, Wassmann P, Noji T, Passow U (1995) On the trophic fate of Phaeocystis pouchetii (Hariot) 6. Significance of Phaeocystis-derived mucus for vertical flux. Neth J Sea Res 33:193-203

Riemann L, Winding A (2001) Community dynamics of freeliving and particle-associated bacterial assemblages during a freshwater phytoplankton bloom. Microb Ecol 42: 274-285

Riemann L, Steward GF, Azam F (2000) Dynamics of bacterial community composition and activity during a mesocosm diatom bloom. Appl Environ Microbiol 66:578-587

Rooney-Varga JN, Giewat MW, Savin MC, Sood S, LeGresley M, Martin JL (2005) Links between phytoplankton and bacterial community dynamics in a coastal marine environment. Microb Ecol 49:163-175

Rousseau V, Leynaert A, Daoud N, Lancelot C (2002) Diatom succession, silicification and silicic acid availability in Belgian coastal waters (Southern North Sea). Mar Ecol Prog Ser 236:61-73

Sapp M, Schwaderer AS, Wiltshire KH, Hoppe HG, Gerdts G, Wichels A (2007) Species-specific bacterial communities in the phycosphere of microalgae? Microb Ecol 53: 683-699

Shannon CE, Weaver W (1963) The mathematical theory of communication. University of Illinois Press, Urbana, IL

Starink M, Bargilissen MJ, Bak RPM, Cappenberg TE (1994) Quantitative centrifugation to extract benthic protozoa from fresh-water sediments. Appl Environ Microbiol 60: $167-173$

Steyaert M, Garner N, Van Gansbeke D, Vincx M (1999). Nematode communities from the North Sea: environmental controls on species diversity and vertical distribution within the sediment. J Mar Biol Assoc UK 79:253-264

Urakawa H, Yoshida T, Nishimura M, Ohwada K (2000) Characterization of depth-related population variation in microbial communities of a coastal marine sediment using 16S rDNA-based approaches and quinone profiling. Environ Microbiol 2:542-554

Vallaeys T, Topp E, Muyzer G, Macheret V, Laguerre G, Rigaud A, Soulas G (1997) Evaluation of denaturing gradient gel electrophoresis in the detection of $16 \mathrm{~S}$ rDNA sequence variation in rhizobia and methanotrophs. FEMS Microbiol Ecol 24:279-285

Vanaverbeke J, Soetaert K, Vincx M (2004a) Changes in morphometric characteristics of nematode communities during a spring phytoplankton bloom deposition. Mar Ecol Prog Ser 273:139-146

Vanaverbeke J, Steyaert M, Soetaert K, Rousseau V, Van Gansbeke D, Parent JY, Vincx M (2004b) Changes in structural and functional diversity of nematode communities during a spring phytoplankton bloom in the southern North Sea. J Sea Res 52:281-292

Van der Gucht K, Sabbe K, De Meester L, Vloemans N, Zwart G, Gillis M, Vyverman W (2001) Contrasting bacterioplankton community composition and seasonal dynamics in two neighbouring hypertrophic freshwater lakes. Environ Microbiol 3:680-690 
Van Duyl FC, Kop AJ (1994) Bacterial production in NorthSea sediments - clues to seasonal and spatial variations. Mar Biol 120:323-337

Van Hannen EJ, Mooij WM, van Agterveld MP, Gons HJ, Laanbroek HJ (1999a) Detritus-dependent development of the microbial community in an experimental system: qualitative analysis by denaturing gradient gel electrophoresis. Appl Environ Microbiol 65:2478-2484

Van Hannen EJ, Zwart G, van Agterveld MP, Gons HJ, Ebert J, Laanbroek HJ (1999b) Changes in bacterial and eukaryotic community structure after mass lysis of filamentous cyanobacteria associated with viruses. Appl Environ Microbiol 65:795-801

von Wintzingerode F, Göbel UB, Stackebrandt E (1997) Determination of microbial diversity in environmental samples: pitfalls of PCR-based rRNA analysis. FEMS Microbiol Rev

Editorial responsibility: Staffan Kjelleberg, Sydney, New South Wales, Australia
21:213-229

Washington HG (1984) Diversity, biotic and similarity indices: a review with special relevance to aquatic ecosystems. Water Res 18:653-694

Wieser W (1953) Die Beziehung zwischen Mundhöhlengestalt, Ernährungsweise und Vorkommen bei freilebenden marinen Nematoden. Ark Zool 4:439-484

Wright SW, Jeffrey SW (1997) High-resolution HPLC system for chlorophylls and carotenoids of marine phytoplankton. In: Jeffrey SW, Mantoura RFC, Wright SW (eds) Phytoplankton pigments in oceanography: guidelines to modern methods. UNESCO, Paris, p 327-341

Xia SQ, Shi Y, Fu YG, Ma XM (2005) DGGE analysis of $16 \mathrm{~S}$ rDNA of ammonia-oxidizing bacteria in chemical-biological flocculation and chemical coagulation systems. Appl Microbiol Biotechnol 69:99-105

Submitted: November 17, 2006; Accepted: May 10, 2007 Proofs received from author(s): July 18, 2007 